\title{
Eksistensi Usaha Kecil Menengah dan Pasar Tradisional dalam Kebijakan Pengembangan Pasar Modern
}

\author{
Ahmad Dakhoir ${ }^{\mathrm{a}, 1}$ \\ ${ }^{a}$ IAIN Palangka Raya, Kalimantan Tengah, Indonesia \\ ${ }^{1}$ ahmad.dakhoir@iain-palangkaraya.ac.id
}

ABSTRACT

Article history:

Received : 2018-02-14

Revised : 2018-06-29

Accepted : 2018-06-30

Keywords:

SME

Traditional market

Policy

Modern market

The growing rapidly of modern market in the mid of traditional markets and Small Medium Enterprises has not become energy and instruments in the development of people's economy in Indonesia. The number of modern retailers should also be utilized by small medium businessmen. This paper is aimed at explaining the existence of Small Medium Enterprises (SMEs) and traditional markets amid the rapidly development of modern market. The dynamic is also felt by SMEs and traditional markets in Palangkaraya Town, Central Kalimantan. The method of this study uses descriptive qualitative approach. The object of study is all markets / modern stores and traditional markets in Palangka Raya Town. Based on the results of the analysis, this study reveals that the establishment of modern stores in Palangka Raya Town has a positive impact in the Palangka Raya Town. It becomes one of the factors encouraging the social and economic growth of the city. While the negative impact is that it threatens the resilience of traditional shops / markets and the similar small businesses and it can trigger social vulnerability (unharmonious).

Copyright () 2018 IAIN Palangka Raya. All rights reserved.

\section{Pendahuluan}

Kehadiran dua model pasar yaitu ritel modern dan pasar tradisional serta Usaha Kecil Menengah (selanjutnya disebut UKM) belum menjadi sebuah kekuatan dan instrumen dalam pembangunan ekonomi nasional di Indonesia. Menteri Koordinator Bidang Perekonomian Darmin Nasution, dahulu pernah menyatakan bahwa beliau menyayangkan ritel modern dan ritel tradisional belum mampu bersinergi dengan baik. Suburnya ritel modern seyogyanya dapat dimanfaatkan oleh pegiat usaha kecil dan pasar tradisional. Darmin menyebutkan,(14) banyak pelaku usaha kecil atau UKM yang mengeluh lantaran produk mereka sulit tembus ke ritel modern untuk dijual di sana, bahkan kalah bersaing dengan pasar atau toko modern.

Dua ritel tersebut saat ini masih berjalan tak searah. Hal ini dapat dilihat dari jarak perkembangan antara pasar tradisional dan pasar modern yang semakin tinggi. Hingga tahun 2018 jumlah supermarket atau hypermart maupun minimart di Indonesia mengalami gradasi yang luar biasa. DOI: 10.23971 /jsam.v14i1.
Sebagaimana data yang dirilis dari Kementerian Perdagangan (Kemendag) RI melalui Direktur Jenderal Perdagangan Dalam Negeri Kemendag, Srie Agustina mengungkapkan bahwa jumlah pasar modern yang ada diseluruh Indonesia mencapai 23.000 unit.(19) Jumlah tersebut mengalami peningkatan sebesar 14 persen dalam tiga tahun terakhir. Pasar modern yang berjumlah 23.000 unit tersebut, ternyata 14.000 unit lebih merupakan kelompok usaha minimarket, sedangkan sisanya adalah supermarket.

Banyak faktor yang menjadi progres perkembangan pasar modern begitu cepat. Kehadiran pasar modern yang memberikan banyak kenyamanan membuat sebagian orang enggan untuk berbelanja ke pasar tradisional. Sementara pasar tradisional harus berhadapan pada situasi dan kondisi pasar yang becek dan bau, tidak praktis dan malas dalam tawar menawar, faktor keamanan seperti copet, dan lain-lain, resiko pengurangan timbangan pada barang yang dibeli, penuh, sesak, dan sejumlah alasan lainnya.(10)

Persoalan kondisi pasar di atas juga menjadi salah satu faktor yang mempengaruhi $\mathrm{W}$ : http://e-journal.iain-palangkaraya.ac.id/index.php/jsam E : Jsam.iainpky@gmail.com 
paradigma berpikir masyarakat. Jumlah kios atau pasar tradisional sudah banyak yang tutup karena sulit bersaing dengan pasar modern. Sekretaris Jendral Asosiasi Pedagang Pasar Seluruh Indonesia (APPSI), Muhammad Maulana menjelaskan, APPSI telah melakukan penyisiran ke beberapa pasar tradisional di sejumlah daerah dan ditemukan berbagai masalah yang menimpa pasar tradisional. Salah satu masalah yang cukup rawan dan perlu diatasi secara cepat adalah berkurangnya jumlah pasar tradisional hingga mencapai 2 ribu pasar karena tergerus oleh keberadaan pasar modern.(16) Jumlah ini kemungkinan akan terus bertambah seiring kehadiran pasar modern yang kian marak. Kondisi semacam ini tentu sungguh memprihatinkan. Prihal yang sama telah dirasakan di kota Bangkok, Thailand yang awalnya memiliki puluhan pasar tradisional, namun kini hanya tersisa dua pasar, sebagai salah satu dampak dari kehadiran puluhan hypermart.

Keberadaan pasar tradisional di wilayah perkotaan dari waktu ke waktu semakin terancam dengan semakin banyaknya pembangunan pasar modern. Pembangunan minimarket dan pasar modern yang telah memberikan fasilitas kenyamanan dalam diri masyarakat dapat berdampak negatif terhadap perekonomian masyarakat, khususnya masyarakat yang memiliki ekonomi rendah yang mendapat penghidupan dari hasil penjualan dagangnya tidak terlalu banyak. Hal ini menjadi bukti bagaimana proses pembangunan pasar modern yang mampu memberikan suatu kenyamanan dan fasilitas yang memadai cenderung dapat merugikan banyak pihak.(7)

Selain pasar tradisional, Usaha Kecil Menengah atau UKM juga mengalami hal yang sama dalam lalu lintas bisnis di Indonesia. UKM yang berhasil bertahan dalam krisis moneter dan ekonomi tahun 1997-1998 sedikit namun masih juga mengalami berbagai guncangan dalam perkembangannya. Produk UKM dalam berbagai jenis masih banyak yang tidak mampu bersaing dengan produk-produk olahan pabrik yang lebih murah, menarik, berjumlah banyak dan memiliki akses kemudahan dalam menembus pasar-pasar modern. Sebaliknya dengan produk UKM yang harus berurusan ijin yang panjang, masalah kemasan, keberlanjutan produk, dan lain-lain sehingga sulit menembus pasar-pasar tradisional seperti hypermart, department store dan toko-toko modern lainnya.

Kondisi UKM dan pasar tradional di atas juga terjadi di Palangka Raya. Kota Palangka Raya yang sedang berkembang dan strategis menjadi wilayah yang prospektif dalam pengembangan bisnis ritel. Hingga tahun 2017 jumlah outlet minimarket di Palangka Raya berjumlah 56 outlet dan 1 hypermart.(20) Kehadiran minimarket dan hypermart tersebut tentu saja berdampak kepada masyarakat, pasar tradisional dan UKM. Tujuan tulisan ini berupaya menemukan peta sebaran perkembangan pasar tradisional, UKM dan kehadiran pasar modern di Palangka Raya. Selanjutnya, tujuan riset ini diarahkan untuk menganalisis perkembangan dan konstruksi UKM dan pasar tradisional terutama dampak pendirian pasar modern dalam memberikan kontribusi pembinaan dan program kemitraan dengan UKM dan pasar tradisional di Palangka Raya.

\section{Kajian Pustaka}

\section{Konsep Usaha Kecil Menengah}

Usaha Mikro, Kecil dan Menegah yang selenjunya disingkat UMKM adalah kegiatan ekonomi yang berskala mikro, kecil dan menengah sebagimana dimaksud dalam UU mengenai Usaha Mikro, Kecil dan Menengah. Menurut Kementerian koperasi dan UKM bahwa yang dimaksud dengan Usaha Kecil (UK), termasuk Usaha Mikro (UMI), adalah entitas usaha yang mempunyai kekayaan bersih paling banyak Rp 200.000.000, tidak termasuk tanah dan bangunan tempat usaha, dan memiliki penjualan tahunan paling banyak Rp 1.000.000.000. Sementara itu, Usaha Menengah (UM) merupakan entitas usaha milik warga negara Indonesia yang memiliki kekayaan bersih lebih besar dari Rp 200.000 .000 s.d. Rp 10.000.000.000, tidak termasuk tanah dan bangunan.(13)

Adapun menurut Badan Pusat Statistik (BPS) memberikan definisi UKM berdasarkan kuantitas tenaga kerja. Usaha kecil merupakan entitas usaha yang memiliki jumlah tenaga kerja 5 s.d 19 orang, sedangkan usaha menengah merupakan entitias usaha yang memiliki tenaga kerja 20 s.d. 99 orang. Sedangkan menurut KepMenKeu Nomor 316/KMK.016/1994 27 Juni 1994 usaha kecil didefinisikan sebagai perorangan atau badan 
usaha yang telah melakukan kegiatan/usaha yang mempunyai penjualan/omset per tahun setinggi-tingginya $\mathrm{Rp} \quad 600.000 .000$ atau aset/aktiva setinggi-tingginya $\mathrm{Rp} 600.000 .000$ (di luar tanah dan bangunan yang ditempati) terdiri dari: (1) badang usaha (Fa, CV, PT, dan koperasi), dan (2) perorangan (pengrajin/industri rumah tangga, petani, peternak, nelayan, perambah hutan, penambang, pedagang barang dan jasa).(13)

Menurut Undang-undang No. 20 Tahun 2008 tentang UMKM, yang disebut dengan Usaha Kecil adalah entitas yang memiliki kriteria sebagai berikut: (1) kekayaan bersih lebih dari Rp 50.000.000,00 (lima puluh juta rupiah) sampai dengan paling banyak $\mathrm{Rp}$ 500.000.000,00 (lima ratus juta rupiah) tidak termasuk tanah dan bangunan tempat usaha; dan (2) memiliki hasil penjualan tahunan lebih dari Rp 300.000.000,00 (tiga ratus juta rupiah) sampai dengan paling banyak Rp 2.500.000.000,00 (dua milyar lima ratus juta rupiah). Sementara itu, yang disebut dengan Usaha Menengah adalah entitas usaha yang memiliki kriteria sebagai berikut: (1) kekayaan bersih lebih dari $\mathrm{Rp}$ 500.000.000,00 (lima ratus juta rupiah) sampai dengan paling banyak Rp 10.000.000.000,00 (sepuluh milyar rupiah) tidak termasuk tanah dan bangunan tempat usaha.(13)

\section{Interpretasi Konsep Pasar Tradisional}

Peraturan Presiden RI No. 112 Tahun 2007, Pasar tradisional adalah pasar yang dibangun dan dikelolah oleh pemerintah, Pemerintah Daerah, swasta, Badan Usaha Milik Negera dan Badan Usaha Milik Daerah termasuk kerjasama dengan swasta dengan tempat usaha berupa toko, kios, los dan tenda yang dimilik/ dikelolah oleh pedagang kecil, menengah, swadaya masyarakat atau kopersasi dengan usaha skala kecil, modal kecil dan dengan proses jual beli barang dagangan melalui tawar menawar. Ditambahkan pula bahwa pasar tradisional merupakan pusat kegiatan sosial ekonomi kerakyatan, dengan demikian pola hubungan ekonomi yang terjadi di pasar tradisional menghasilkan terjalinnya interaksi sosial yang akrab antara pedagang-pembeli, pedagang-pedagang dan pedagang-pemasok yang merupakan warisan sosial untuk mewakili kebutuhan bersosialisasi antar individu.(2)

\section{Konsep Pasar Modern}

Menurut Peraturan Presiden No. 112 Tahun 2007, pasar adalah area tempat jual beli barang dengan jumlah penjual lebih dari satu baik yang disebut sebagai pusat perbelanjaan, pasar tradisional, pertokoan, mall, plasa, pusat perdagangan maupun sebutan lainnya. Pasar modern adalah pasar yang dikelola dengan manajemen modern, umumnya terdapat di kawasan perkotaan, sebagai penyedia barang dan jasa dengan mutu dan pelayanan yang baik kepada konsumen (umumnya anggota masyarakat kelas menengah ke atas). Seperti yang dinyatakan oleh Sinaga (2004) dalam makalahnya pada Bahan Pertemuan Nasional Tentang Pengembangan Pasar Tradisional menyatakan contoh pasar modern antara lain mall, supermarket, departement store, shopping centre, waralaba, toko mini swalayan, pasar serba ada, toko serba ada dan sebagainya.

Toko modern adalah toko dengan sistem pelayanan mandiri terintegrasi yang menjual berbagai barang secara eceran ataupun grosir yang berbentuk perkulakan, yang termasuk kedalam toko modern meliputi minimarket, supermarket, departemen store, dan hypermarket. Minimarket adalah sarana atau tempat usaha untuk melakukan penjualan barang-barang kebutuhan sehari-hari secara eceran langsung kepada pembeli akhir dengan cara swalayan yang luas lantai usaha kurang dari $400 \mathrm{~m}^{2}$.

Menurut Peraturan Presiden Nomor 114 Tahun 2007, Peraturan Menteri Perdagangan Nomor 70 Tahun 2013 dan Peraturan Daerah Kota Palangka Raya Nomor 17 Tahun 2014, bahwa zona jarak radius yang ideal antara toko modern (minimarket) minimal $0.5 \mathrm{Km}^{2}$ dengan pasar tradisional dan dari usaha kecil sejenis. Secara keseluruhan syarat pendirian pasar modern atau toko modern adalah :

a. Zona jarak toko modern dengan pasar/toko tradisional dan usaha kecil

b. Jumlah Minimum Penduduk Pendukung (Jiwa) 
c. Struktur penduduk menurut mata pencaharian dan pendidikan

d. Tingkat kepadatan dan pertumbuhan penduduk pada tahun terakhir.

e. Tingkat Pendapatan Ekonomi Rumah Tangga

f. Rencana Kemitraan dengan usaha mikro, kecil dan menengah

g. Penyerapan tenaga kerja lokal

h. Ketahanan dan pertumbuhan pasar rakyat sebagai sarana bagi UMKM

i. Ketersediaan fasilitas sosial dan fasilitas umum

j. Dampak positif dan negatif atas pendirian pusat perbelanjaan dan toko modern terhadap pasar rakyat dan toko eceran tradisional yang telah ada sebelumnya

k. Tanggungjawab sosial perusahaan (CSR) yang diarahkan untuk berdampingan bagi pengelolaan pasar rakyat dan/atau masyarakat dilingkungan sekitar lokasi usaha.

\section{Metodologi Penelitian}

Tulisan ini merupakan penelitian kualitatif lapangan yang bersifat deskriptif. Penelitian lapangan ini pada hakikatnya merupakan metode untuk menemukan secara spesifik dan realis tentang apa yang sedang terjadi pada suatu saat ditengah-tengah kehidupan masyarakat.(12) Paper ini bertujuan agar peneliti dapat mengetahui dan menggambarkan dengan jelas dan rinci tentang tujuan tulisan ini yang berupaya menemukan peta sebaran perkembangan pasar tradisional, UKM dan kehadiran pasar modern di Palangka Raya. Selanjutnya, tujuan riset ini diarahkan untuk menganalisis perkembangan dan konstruksi UKM dan pasar tradisional terutama dampak pendirian pasar modern dalam memberikan kontribusi pembinaan dan program kemitraan dengan UKM dan pasar tradisional di Palangka Raya. Adapun pendekatannya menggunakan pendekatan kualitatif deskriptif.(4) Pendekatan kualitatif deskriptif sebagaimana pendapat Moleong adalah suatu penelitian yang akan mengumpulkan kata-kata, gambar, dan bukan angka, dengan demikian, laporan penelitian akan berisi kutipan-kutipan data untuk memberi gambaran penyajian laporan tersebhtber
Teknik pengumpulan data merupakan langkah yang paling strategis dalam melakukan sebuah riset. Teknik yang mendukung yaitu dengan observasi, wawancara dan dokumentasi.(6) Adapun teknik analisis data yaitu menggunakan teknik pengumpulan materi sebanyak mungkin tanpa proses pemilihan yang ada hubungannya dengan data terkait, setelah itu melakukan proses eliminasi data dengan menajamkan, menggolongkan dan memilih mana data yang relevan dan yang tidak relevan dan kemudian dilanjutkan dengan mengorganisasikan data. Selanjutnya melakukan proses penyajian data yang sudah relevan dipaparkan secara ilmiah oleh peneliti dengan tidak menutup kekurangannya. Hasil penelitian akan digambarkan sesuai dengan apa yang didapat dari proses penelitian tersebut. Teknik selanjutnya melakukan penarikan kesimpulan dengan melihat kembali tahap eliminasi data dan penyajian data tidak menyimpang pada data yang diambil.(5)

\section{Hasil dan Pembahasan}

\section{Profil dan Penduduk Kota Palangka Raya}

Berdasarkan Data BPS Kota Palangka Raya Tahun 2014, Penduduk Kota Palangka Raya sebesar 229.559 jiwa, dengan distribusi terbanyak berada di Kecamatan Jekan Raya dan Kecamatan Pahandut. Jumlah penduduk Kecamatan Jekan Raya mencapai 119.178 jiwa atau sekitar 51,91\%. Sedangkan di Kecamatan Pahandut sebesar 80.324 jiwa atau sekitar 34,99\%. Adapun sebaran penduduk Kota Palangka Raya dapat dilihat pada tabel 1,2 dan 3 berikut.

\section{Tabel 1}

\section{Jumlah Penduduk Berdasarkan Kecamatan di Kota Palangka Raya Tahun 2009-2013}

\begin{tabular}{|c|c|c|c|c|c|c|}
\hline \multirow[b]{2}{*}{ No } & \multirow[b]{2}{*}{ Kecamatan } & \multicolumn{4}{|c|}{ Jumlah Penduduk (Jiwa) } & \multirow{2}{*}{$\begin{array}{c}\text { Jumlah } \\
\text { Kepala } \\
\text { Keluarga }\end{array}$} \\
\hline & & $\begin{array}{l}\text { Laki- } \\
\text { laki }\end{array}$ & Perempuan & Jumlah & $\begin{array}{c}\text { Persen } \\
(\%)\end{array}$ & \\
\hline 1 & Pahandut & 40.977 & 39.347 & 80.324 & 34.99 & 19.807 \\
\hline 2 & Sabangau & 7.714 & 7.169 & 14.883 & - & 3.545 \\
\hline 3 & Jekan Raya & 60.790 & 58.388 & 119.178 & 51,91 & 31.037 \\
\hline 4 & Bukit Batu & 6.337 & 5.858 & 12.195 & - & 2.960 \\
\hline 5 & Rakumpit & 1.596 & 1.423 & 3.019 & - & 710 \\
\hline & Jumlah & 117.414 & 112.185 & 229.599 & 100 & 58.059 \\
\hline
\end{tabular}

Badan Pusat Statistik Kota Palangka Raya 2014 
Terlepas Berdasarkan Standar Nasional Indonesia (SNI) 03-1733-2004 tentang tata cara perencanaan lingkungan perumahan di perkotaan terkait penataan lokasi perdagangan barang dan niaga bahwa pendirian 1 (satu) unit toko modern didukung oleh minimal 250 jiwa. Oleh karena itu berdasarkan tabel di atas, maka gambaran pengembangan toko modern di Kota Palangka Raya dapat dilihat pada tabel berikut:

\section{Tabel 2}

\section{Daya Tampung Maksimum Toko Modern Berdasarkan Jumlah Penduduk di Kota Palangka Raya}

\begin{tabular}{|c|c|l|l|c|}
\hline No & Kecamatan & $\begin{array}{c}\text { Jumlah } \\
\text { penduduk }\end{array}$ & $\begin{array}{c}\text { Jumlah } \\
\text { Toko } \\
\text { Modern }\end{array}$ & $\begin{array}{c}\text { Jumlah } \\
\text { Toko } \\
\text { Modern } \\
\text { Ideal }\end{array}$ \\
\hline 1 & Pahandut & 80.324 & 210 & 321 \\
\hline 2 & Sabangau & 14.883 & 10 & 60 \\
\hline 3 & Jekan Raya & 119.178 & 317 & 477 \\
\hline 4 & Bukit Batu & 12.195 & 3 & 49 \\
\hline 5 & Rakumpit & 3.019 & - & 12 \\
\hline & Total & 229.599 & 540 & 930 \\
\hline
\end{tabular}

Sumber : Badan Pusat Statistik Kota Palangka Raya Tahun 2015

Berdasarkan tabel di atas daya tampung maksimum toko modern berdasarkan jumlah penduduk di Kota Palangka Raya adalah 930 unit toko modern. Jumlah tersebut termasuk keberadaan minimart, supermart, hypermart, department store dan sejenisnya. Potensi peningkatan dan perkembangan jumlah pasar/toko modern berdasarkan jumlah penduduk di atas, sebenarnya dapat menjadi kekuatan bagi pemerintah untuk membangkitkan iklim bisnis masyarakat dan UKM disekitar toko/pasar modern tersebut.

Tingkat kepadatan dan pertumbuhan penduduk kota Palangka Raya juga signifikan. Jika melihat data statistik kepadatan dan pertumbuhan penduduk kota Palangka Raya tahun 2015 cukup tinggi. Tingkat kepadatan penduduk Kota Palangka Raya dapat dilihat sebagaimana tabel berikut :
Tabel 3

Pertumbuhan dan Kepadatan Penduduk Kota Palangka Raya Tahun 2015

\begin{tabular}{|l|c|c|c|}
\hline Kecamatan & $\begin{array}{c}\text { Luas } \\
\text { Wilayah } \\
\left(\mathrm{Km}^{2}\right)\end{array}$ & $\begin{array}{c}\text { Jumlah } \\
\text { Penduduk }\end{array}$ & $\begin{array}{c}\text { Kepadatan } \\
\left(\mathrm{Jiwa}^{2} / \mathrm{Km}^{2}\right)\end{array}$ \\
\hline Pahandut & 117,25 & 85.591 & 729,99 \\
Sabangau & 583,5 & 15.859 & 27,18 \\
Jekan Raya & 352,62 & 126.993 & 360,14 \\
Bukit Batu & 572 & 12.871 & 22,50 \\
Rakumpit & $1,053,14$ & 3.186 & 3,03 \\
\hline & $2.678,51$ & 244.500 & 91,28 \\
\hline
\end{tabular}

Sumber: Badan Pusat Statistik Kota Palangka Raya Tahun 2015

Berdasarkan tabel 3, kepadatan penduduk terbesar berada di kecamatan Pahandut dan Jekan Raya. Oleh karena itu pengembangan toko modern saat ini mengarah pada dua kecamatan tersebut dan tidak menutup kemungkinan pengembangan toko modern mengarah pada kecamatan lain seiring dengan laju pertumbuhan dan kepadatan penduduk. Jika menengok pada teori pengembangan UKM dan pasar tradisional, peran pasar modern yang jumlahnya tidak sedikit tersebut seyogyanya dapat turut serta mengembangkan UKM yang lebih di arahkan kepada daya saing dengan upaya peningkatan adaptasi terhadap kebutuhan pasar, pemanfaatan hasil inovasi dan penerapan teknologi.(1) Ekspekstasi dan optimisme ini juga diperkuat oleh Tambunan sebagaimana dikutip oleh Alyas dan Muhammad Rakib, bahwa pengembangan UKM dan pasar tradisional sangat dipengaruhi oleh peran pemerintah dan pasar modern, baik langsung maupun secara tidak langsung.(3)

\section{Kemitraan UKM, Pasar Tradisional dan Penyerapan Tenaga Kerja Lokal}

Adapun terkiat dengan pembinaan dan program kemitraan antara UKM, pasar tradisional dan pasar modern masih belum optimal. Berdasarkan hasil wawancara dan observasi di lapangan, pihak manajemen telah mempunyai perencanaan kemitraan dengan UMKM lokal, namun prosedur untuk dapat menembus dan menjual produk lokal ke dalam sistem pasar modern cukup panjang dan cenderung rumit. Apabila UMKM lokal ingin menjual produknya ke Alfamart maka mereka 
harus mendaftarkan produknya ke PT. Sumber Alfariat Triwijaya Tbk di Banjarmasin. Sedangkan jika UMKM lokal ingin menjual produk mereka ke Foodmart maka UMKM lokal harus mendaftarkan produk mereka ke Hypermart untuk diverifikasi oleh pihak manajemen sebelum didistribusikan ke outlet Foodmart. Hal inilah yang menyebabkan masih minimnya produk lokal yang dijual di toko modern.

Berdasarkan hasil wawancara dan observasi di lapangan, jumlah karyawan Foodmart rata-rata 6-7 orang sedangkan Alfamart dan indomart rata-rata memiliki karyawan sebanyak 8-10 orang. Berdasarkan asal SDM rata-rata penyerapan tenaga kerja lokal baik foodmart maupun alfamart sebesar $80 \%$ dan sisanya berasal dari Kabupaten di Kalimantan Tengah dan Kota Banjarmasin Kalimantan Selatan. Sementara manajer toko alfamart, indomart dan foodmart berasal dari Pulau Jawa yang merupakan pegawai tetap yang telah mengikuti sistem penjenjangan karir pihak managemen sesuai peraturan yang berlaku di perusahaan. Karyawan foodmart selain manager merupakan karyawan kontrak (6 bulan) dan akan menjadi karyawan tetap apabila telah menjalani minimal 2 kali kontrak. Sedangkan karyawan Alfamart merupakan karyawan kontrak (1 tahun) dan akan menjadi karyawan tetap apabila menjalani minimal 2 kali kontrak. Berdasarkan hasil wawancara, karyawan akan mendapatkan promosi jabatan dan karir apabila telah menjadi karyawan tetap dan memiliki kinerja yang sangat baik.

Sistem pengupahan di toko modern telah menerapkan sistem pengupahan sesuai UMR Kota Palangka Raya. Namun terdapat perbedaan pada jumlah upah yang diterima karyawan. Di foodmart karyawan mendapatkan gaji Rp. 1,8 juta/bulan sudah termasuk biaya konsumsi dan trasportasi sehari-hari. Sedangkan karyawan Alfamart, hypermart, Indomart mendapatkan gaji Rp. 2,1 juta/bulan termasuk biaya konsumsi dan transportasi sehari-hari. Namun karyawan baik karyawan Alfamart dan Foodmart telah mendapatkan jaminan dari BPJS kesehatan dan BPJS ketenagakerjaan.(8)

Berdasarkan hasil analisa penulis, penyerapan tenaga kerja lokal masih terbatas pada zona Kalteng dan Kota Palangka Raya.
Toko modern belum melakukan penyerapan tenaga kerja lokal berdasarkan zonasi lokasi tempat keberadaan toko modern. Apabila hal tersebut diterapkan maka keberadaan toko modern secara tidak langsung akan mendorong penurunan angka pengangguran di tempattempat sekitar pasar modern tersebut.

Pembahasan tentang kemitraan dan rencana kemitraan di atas, apabila dijalankan dengan komitmen yang baik maka keberadaan toko modern dapat mendorong ketahanan dan pertumbuhan pasar rakyat bagi UMKM lokal di sekitar lokasi. Berdasarkan observasi dan wawancara, harga barang-barang kebutuhan pokok lebih lebih murah bahkan sama dengan toko-toko tradisional kecuali harga rokok, minuman kemasan dan kebutuhan skunder. Namun harga barang-barang tersebut bisa relatif lebih murah dari harga biasanya pada saat promo. Berdasarkan hasil wawancara, promo dilakukan 1-2 kali setiap 2 minggu dan setiap akhir pekan. Dampak negatif yang ditimbulkan, toko-toko tradisional di sekitar toko modern yang dimaksud merasa ditinggalkan oleh pelanggan pada jadwaljadwal promo sehingga berdampak pada pendapatan pedagang-pedagang sekitar bahkan ada yang sampai gulung tikar terutama pada lokasi yang terdapat foodmart dan alfamart yang jaraknya tidak memenuhi syarat (berdekatan secara zonasi). Sedangkan dampak positifnya, masyarakat sekitar dapat membeli barang-barang kebutuhan sehari-hari dengan harga yang lebih murah pada saat promo. Selain itu dampak positif juga dirasakan oleh sebagian kecil pedagang tradisional, karena promo dapat dimanfaatkan untuk membeli barang-barang yang nantinya dapat dijual kembali dengan harga yang lebih tinggi di toko-toko mereka.

\section{Ketersediaan Fasilitas Sosial dan Fasilitas Umum Pasar Modern}

$\begin{array}{cccr}\text { Eksistensi } & \text { pasar } & \text { modern } & \text { dalam } \\ \text { pembangunan } & \text { ekonomi } & \text { tidak } & \text { hanya } \\ \text { meningkatkan } & \text { fungsi } & \text { profit } & \text { dan }\end{array}$
mengembangkan pertumbuhan ekonomi makro namun juga memperhatikan berbagai aspek seperti fungsi sosial kepada masyarakat sekitar. Fungsi sosial pasar modern terlihat dari ada tidaknya ketersediaan fasilitas sosial dan fasilitas umum untuk membantu masyarakat sekitar. 
Berdasarkan hasil observasi di lapangan, $100 \%$ toko modern belum memiliki fasilitas sosial. Sedangkan toko Modern yang memiliki fasilitas umum seperti ATM dan tempat sampah adalah sebagaimana tabel berikut:

Tabel 4

Jumlah Pasar Modern di Kota Palangka Raya

\begin{tabular}{|c|c|c|c|c|}
\hline No & $\begin{array}{c}\text { Pasar } \\
\text { Modern }\end{array}$ & Jm & Fas. Sosial & Fasilitas umum \\
\hline 1. & Foodmart & 19 & - & $\begin{array}{l}\text { Rata-rata } \\
\text { memiliki toilet, } \\
\text { Rata-rata belum } \\
\text { memiliki tempat } \\
\text { sampah, } \\
\text { Rata-rata } \\
\text { memiliki parkir } \\
\text { yang ideal, } \\
1 \text { unit yang } \\
\text { memiliki } \\
\text { fasilitas atm }\end{array}$ \\
\hline 2. & Alfamart & 11 & - & $\begin{array}{l}\text { Rata-rata } \\
\text { memiliki toilet, } \\
\text { Rata-rata } \\
\text { memiliki tempat } \\
\text { sampah, } \\
\text { Rata-rata } \\
\text { memiliki tempat } \\
\text { parkir ideal, }\end{array}$ \\
\hline 3. & Indomart & 25 & - & $\begin{array}{l}\text { Toilet, } \\
\text { Memiliki } \\
\text { Tempat Sampah }\end{array}$ \\
\hline 4. & Hypermart & 1 & $\begin{array}{l}\text { Mushalla, } \\
\text { ATM, } \\
\text { Parkir, } \\
\text { Fasilatas } \\
\text { Permainan } \\
\text { Anak-anak }\end{array}$ & $\begin{array}{l}\text { Toilet, } \\
\text { Memiliki } \\
\text { Tempat Sampah }\end{array}$ \\
\hline
\end{tabular}

observasi tim sosial ekonomi Kota Palangka Raya tahun 2015

Berdasarkan tabel di atas, hypermart dan 1 unit foodmart telah memiliki fasilitas umum, ATM dan $100 \%$ toko modern memiliki toilet. Sementara dalam pengolahan Sampah, 100\% Alfamart memiliki tempat penampungan sampah sedangkan foodmart belum memiliki tempat penampungan sampah.

Ketersediaan fasilitas sosial dan fasilitas umum yang belum optimal pada pasar modern baik alfamart, dan indomart termasuk hypermart di Kota Palangka Raya seyogyanya harus ditingkatkan. Hal ini sebagai amanah pembangunan ekonomi dan lingkungan yang nyaman ditengah berkembangnya kota yang semakin pesat. Jika melihat syarat pendirian pasar modern dalam beberapa peraturan, pasar modern wajib memenuhi syarat-syarat yaitu memperhatikan zona jarak toko modern dengan pasar/toko tradisional dan usaha kecil, adanya data pendukung jumlah minimum penduduk pendukung (jiwa), harus memperhatikan struktur penduduk menurut mata pencaharian dan pendidikan, harus memperhatikan tingkat kepadatan dan pertumbuhan penduduk pada tahun terakhir, harus memperhatikan tingkat pendapatan ekonomi rumah tangga. Selain itu pasar modern juga harus memiliki potensi rencana kerja atau program kemitraan dengan usaha mikro, kecil dan menengah, mampu menyerap tenaga kerja lokal, ketahanan dan pertumbuhan pasar rakyat sebagai sarana bagi UMKM, harus mampu memetakan potensi dampak positif dan negatif atas pendirian pusat perbelanjaan dan toko modern terhadap pasar rakyat dan toko eceran tradisional yang telah ada sebelumnya. Pasar modern juga harus menyalurkan dana tanggungjawab sosial perusahaan (CSR) yang diarahkan untuk berdampingan bagi pengelolaan pasar rakyat atau masyarakat dilingkungan sekitar lokasi usaha, serta syarat yang terakhir yaitu pasar modern harus mampu menyiapkan dan menyediakan fasilitas sosial dan fasilitas umum.

Potret belum adanya ketersediaan fasilitas sosial dan fasilitas umum pada beberapa pasar modern di Palangka Raya menunjukkan perlu adanya dorongan dan dukungan pemerintah untuk mengembangkan kembali fungsi pasar modern dalam 2 aspek tersebut. yaitu fungsi pengembangan market modern dan fungsi sosial sebuah pasar yang dekat dengan masyarakat.

\section{Dampak Sosial-Ekonomi Pendirian Pasar Modern di Kota Palangka Raya}

Berdasarkan Peraturan Presiden Nomor 114 Tahun 2007, Peraturan Menteri Perdagangan Nomor 70 Tahun 2013 dan 
Peraturan Daerah Kota Palangka Raya Nomor 17 Tahun 2014, bahwa zona jarak radius yang ideal antara toko modern (minimarket) minimal $0.5 \mathrm{Km}^{2}$ dengan pasar tradisional dan dari usaha kecil sejenis. Berdasarkan hasil observasi di sekitar 56 toko modern, keberadaan dari 56 toko modern rata-rata berdekatan dengan pasar/toko tradisional dan usaha kecil sejenisnya. Misalnya toko sembako, toko kelontong, bahkan dekat dengan toko modern yang sejenis seperti minimarket, swalayan, koperasi dan lain-lain. Berdasarkan Pasal 12 angka 1 Peraturan Daerah Kota Palangka Raya Nomor 17 Tahun 2014 yang mengatur tentang jarak toko modern dengan pasar tradisional dan usaha kecil, maka 56 toko modern tidak memenuhi persyaratan pendirian toko modern.

a. Dampak Sosiologis

Keberadaan pasar modern dalam dimensi masyarakat menimbulkan beragam dampak. Salah satunya adalah dampak sosiologis. Dampak dibidang sosial bahwa pendirian toko modern di Kota Palangka Raya telah memberikan energi semangat dalam pembinaan UMKM seperti pengusaha rumahan seperti pengusaha roti, dapat menampung produk UMKM lokal Palangka Raya dan Provinsi Kalimantan Tengah. Sebagaimana syarat pendirian pasar modern, kehadiran pasar modern sudah seharusnya mengakomodasi dan mampu menjadi pendampingan bagi UMKM sekitar. Fungsi dan peran sosial pasar modern lainya adalah menampung fasilitas sosial seperti ATM, menyerap tenaga kerja lokal hingga $80 \%$, konsumen leluasa dalam memarkir alat transportasi karena lahan parkir yang luas dan gratis, terciptanya akses memperoleh kebutuhan rumah tangga karena berada dekat dengan pelanggan seperti komplek perumahan, adanya kemudahan berbelanja karena toko modern (foodmart, alfamart dan indomart) di kota Palangka Raya serba komplit, memiliki tata niaga dan pelayanan prima terhadap para konsumen, toko modern memiliki daya tarik fisik yang luar biasa, belanja berkonsep wisata, pelayanan pembayaran praktis (seperti credit card), produk bersih tak berdebu dan jarang yang kadaluwarsa, penataan dan penempatan produk yang rapi dan berklaster, jam operasional toko modern tak terbatas (namun untuk saat ini masih terbatas hingga jam 10 malam).(9)

Dampak sosial pendirian pasar modern selanjutnya adalah adanya pembelian beberapa produk yang bebas dan terpampang secara terbuka atau fulgar. Peletakan posisi produk-produk sensitif yang masih terbuka dan terpampang juga berdampak terhadap daya beli masyarakat di bawah umur, dan remaja. Seperti penjualan kondom yang terpampang jelas di depan etalase dan rak-rak diplay.

Aspek sosiologis lainnya yaitu pasar modern telah menambah sampah di masyarakat sekitar karena belum memiliki tempat yang layak dan pengolahan sampah sendiri. Belum adanya keterlibatan aksi nyata terhadap pengelolaan sampah tersebut, tentu saja berdampak pada menambah kuantitas sampah. Selain itu pasar modern juga menambah makin tersudutnya toko/pasar/kios tradisional yang tidak memiliki bangunan fisik yang menarik sebagaimana pasar modern.

Dampak sosioligis pendirian pasar modern secara langsung juga dapat dirasakan bagi pengusaha property seperti pemilik ruko (rumah dan toko) untuk menambah penghasilan pemilik gedung (ruko/toko dll) tersebut karena toko modern menggunakan hak sewa yang tidak sebentar. Sehingga biaya sewa yang tidak hanya 1 tahun atau 2 tahun itu berdampak juga terhadap penghasilan pemilik ruko.

b. Dampak Ekonomi

Dominasi terbesar dampak pendirian pasar modern di Indonesia termasuk di Palangka Raya, adalah dampaknya terhadap kehidupan perekonomian Kota Palangka Raya. Adapun dampak ekonomi pendirian toko modern alfamart, foodmart dan indomart adalah adanya penguatan dan peningkatan omset UMKM (ritel roti) sekitar. Dampak ekonomi 
selanjutnya yang berkontribusi sangat besar bagi masyarakkat terutama masyarakat lokal adalah meningkatnya penghasilan ekonomi tenaga kerja lokal karena banyak tenaga kerja muda yang berasal dari lokal telah bergabung pada pasar-pasar modern tersebut.

Berdirinya pasar modern, yang telah masuk di berbagai sudut wilayah, telah banyak menghemat biaya transportasi karena berada dekat kepada pelanggan seperti komplek perumahan, hemat biaya transportasi dan hemat tenaga karena toko modern (foodmart, alfamart dan indomart) di kota Palangka Raya memiliki produk serba komplit. Selain itu juga banyak memberi manfaat ekonomis karna banyak memberi fasilitas diskon sehingga membantu konsumen memperoleh harga lebih murah.

Pentingnya kehadiran pasar modern berdasarkan fakta di atas tentu dapat menjadi kunci pengembangan UKM dan tentu saja berujung pula pada kesejahteraan masyarakat. Kontribusi positif pengembangan pasar modern selaras dengan pandangan Einsiedel, yang menyatakan bahwa pembangunan masyarakat, merupakan suatu "proses" dimana usaha-usaha atau potensi-potensi yang dimiliki masyarakat diintegrasikan dengan sumber daya yang dimiliki pemerintah, untuk memperbaiki kondisi ekonomi, sosial, dan kebudayaan, dan mengintegrasikan masyarakat di dalam konteks kehidupan berbangsa, serta memberdayakan mereka agar mampu memberikan kontribusi secara penuh untuk mencapai kemajuan pada level nasional.(11)

Namun demikian, meski dampak ekonomi pendirian pasar modern sebenarnya sangat besar bagi pertumbuhan ekonomi sebuah daerah, dampak lain yang ditimbulkan berdirinya toko modern seperti foodmart, alfamart dan indomart di kota Palangka Raya ternyata telah mengurangi jumlah pembeli umum pada kios kecil/tradisional disekitarnya. Tidak hanya itu, pasar modern secara perlahan namun pasti juga mengurangi jumlah pembeli tetap, masih tinggi dalam menarif biaya sewa terhadap pedagang kaki lima yang berjualan di depan toko modern dengan biaya tinggi (seperti Rp. 750.000,/bulan).(17) Selain itu adanya kerawanan baliho roboh, tidak menggunakan hak tawar (negosiasi), tidak memiliki kepastian dalam penetapan standar harga (fluktuasi daftar harga), dan menumbuhkan bibit-bibit kecemburuan sosial bagi pasar dan toko tradisional sebelumnya.

Adapun dampak negatif dibidang ekonomi pendirian toko modern di kota Palangka Raya adalah dengan strategi marketing, membuat harga suatu jenis barang menjadi lebih murah, dan menjadikan harga barang yang lain menjadi lebih mahal dibandingkan dengan harga di pasar/toko/kios tradisional, namun dalam hal harga kebutuhan pokok masih relatif sama dengan harga di kios tradisional. Dampak negatif selanjutnya adalah toko/pasar tradisional mengalami penurunan jumlah pendapatan, penurunan jumlah pendapatan pedagang kelontong terbukti dari jumlah komoditas yang menurun seperti susu, beras, snack makanan ringan anak-anak, roti, mie instan, jenis-jenis minuman, deterjen, minyak goreng, telor, sabun, sampo dan kebutuhan pokok yang lain. Selain itu, dampak negatif ekonomi lainnya adalah tersudutkannya image toko/pasar/kios tradisional secara alamiah. Dampak yang paling mengerikan adalah toko/pasar/kios tradisional gulung tikar, karena harga kebutuhan pokok relatif sama dengan harga kebutuhan pokok di toko/pasar tradisional, kecuali harga kebutuhan skunder seperti rokok yang berharga lebih mahal dari toko/pasar tradisional. Hal ini sesuai dengan pengakuan pemilik kios-kios kecil disekitar toko modern Kota Palangka Raya yang menyatakan:

"dulu asalnya kami banyak menjual minyak tanah, minyak goreng, sekarang tidak lagi menjual barang tersebut karena sudah lengkap tersedia di foodmart di depan toko saya ini." Pengakuan lainnya adalah: "dulu sebelum ada toko modern itu, penghasilan kami hingga Rp. 600.000,-, tetapi saat ini hanya Rp. 400.000,- perhari paling banyak."'(15) 
Guna mengembalikan kekokohan pasar tradisional dan UKM seyogyanya dapat memperkuat utamanya aspek Sumber Daya Manusia yang menjadi motor bisnis pasar tradisionl dan UKM tersebut. Kehadiran kualitas skill karyawan pasar tradisional dan UKM menjadi sangat menentukan dalam membangun sistem untuk mampu berdaya saing. Wahyuningtias menyatakan, dengan adanya peningkatan kualitas karyawan diharapkan dapat membangun sinergi dengan peningkatan kapasitas produksi.(18)

\section{Tanggung Jawab Sosial Perusahaan (CSR) Pasar Modern}

Corporate Social Responsibility (CSR) adalah komitmen usaha untuk beroperasi secara legal dan etis yang berkonstribusi pada peningkatan kualitas kehidupan karyawan dan keluarganya, komunitas lokal dan masyarakat luas dalam rangka mewujudkan pembangunan berkelanjutan. Berdasarkan hasil wawancara, karyawan toko modern belum memahami komitmen perusahaan mereka terkait pelaksanaan tanggung jawab sosial perusahaan. Namun karyawan senantiasa berpartisipasi pada kegiatan-kegiatan yang dilakukan masyarakat sekitar dalam bentuk memberikan sumbangan (dana) apabila ada permintaan sumbangan yang datang ke toko. Biasanya toko memberikan sumbangan Rp.100 ribu untuk sumbangan masjid yang bersumber dari kelebihan dari uang belanja, dengan menawarkan dan menghimbau kepada pembeli untuk mendonasikan uang kelebihan tersebut. Hal ini dilaksanakan biasanya pada bulan ramadhan.

\section{Kesimpulan}

Berdasarkan hasil observasi, sebaran konstruksi toko modern telah mulai memenuhi Kota Palangka raya. Terkait zona jarak radius $0,5 \mathrm{~km}^{2}$ antara toko modern dengan pasar/toko tradisional maka 56 unit toko modern tidak memenuhi syarat. Dimana rata-rata toko modern tersebut mempuyai jarak yang relatif dekat dengan toko/pasar tradisional dan usaha kecil sejenisnya. Berdasarkan jumlah penduduk minimal pendukung, maka daya tampung maksimum toko modern di Kota Palangka Raya adalah 930 unit termasuk minimarket, hypermart, supermarket, departemen store dan sejenisnya. Berdasarkan tingkat kepadatan dan pertumbuhan penduduk di Kota Palangka Raya, maka perkembangan toko modern mengarah pada dua kecamatan yaitu Kecamatan Pahandut dan Jekan Raya. Namun tidak menutup kemungkinan pendirian toko modern di Kecamatan lain dapat dikembangkan seiring dengan laju pertumbuhan dan tingkat kepadatan penduduk. Berdasarkan kondisi di lapangan, program kemitraan toko modern dengan usaha mikro, kecil dan menengah (UMKM) telah didokumentasikan namun belum terimplementasi dengan baik karena kurangnya komitmen dan pengawasan yang masih minim. Berdasarkan hasil observasi, toko modern telah menyerap $75 \%$ tenaga kerja lokal dengan sistem pengupahan sesuai Upah Minimum Kota (UMK). Keberadaan pasar modern secara umum memiliki 2 dampak yang harus diperhatikan yaitu, untuk dampak positif pendirian toko modern di Kota Palangka Raya dapat mendorong pertumbuhan sosial dan ekonomi kota. Sedangkan dampak negatifnya adalah mengancam ketahanan toko/pasar tradisional dan usaha kecil sejenisnya serta dapat memicu kerawanan sosial (disharmonisasi). Terkait dengan CSR, toko modern belum menerapkan program tanggungjawab sosial perusahaan (CSR) pada masyarakat sekitar sesuai dengan peraturan yang berlaku.

\section{Daftar Pustaka}

1. Afifuddin. Pengantar Administrasi Pembangunan. Bandung: CV. Alfabeta, 2010.

2. Aliyah I. Penguatan Sinergi Antara Pasar Tradisional Dan Modern Dalam Rangka Mewujudkan Pemerataan Pembangunan Ekonomi Kerakyatan [Online]. JA! UBL 4, 2014.

http://jurnal.ubl.ac.id/index.php/ja/article/view /531 [17 Apr. 2018].

3. Alyas. Strategi Pengembangan Usaha Kecil dan Menengah dalam Penguatan Ekonomi Kerakyatan (Studi Kasus pada Usaha Roti Maros di Kabupaten Maros). Sosiohumaniora 19, 2017.

4. Arikunto S. Manajemen Penelitian. Jakarta: Rineka Cipta, 2003. 
5. Bungin MB. Analisis Data Penelitian Kualitatif. Jakarta: Raja Grafindo Persada, 2005.

6. Bungin MB. Penelitian Kualitatif: Komunikasi, Ekonomi, Kebijakan Publik, dan Ilmu Sosial Lainnya. Jakarta: Kencana, 2008.

7. Candrawati A. KS. Pasar Modern dan Pasar Tradisional Dalam Gaya Hidup Masyarakat Di Kabupaten Tabanan, Provinsi Bali. JPAP: Jurnal Penelitian Administrasi Publik 1, 2015.

8. F B. Wawancara. 2017.

9. GHD. Wawancara. 2017.

10. Indra. Pasar Tradisional di Tengah Kepungan Pasar Modern [Online]. Indra KH: 2007. https://indrakh.wordpress.com/2007/09/03/pas ar-tradisional-di-tengah-kepungan-pasarmodern/ [8 Jan. 2018].

11. Luz, A E. Success and Failure of some Community Development in Batanggas. Philipina: University of the Philippines A Community Development Research Counsiel Publication, 1968.

12. Mardalis. Metode Penelitian Suatu Pendekatan Proposal. Jakarta: Bumi Aksara, 2004.

13. Muditomo A. Mencermati Peran Pemerintah dalam Pengembangan Koperasi \& UMKM di Indonesia. Praktisi Perbankan BUMN, 2012.

14. Nasution D. UKM Ngaku Sulit Tembus Ritel, Menko Darmin: Pasar Modern Wajib Tampung! https://economy.okezone.com/: [date unknown]. https://economy.okezone.com/read/2017/10/0 4/320/1788516/ukm-ngaku-sulit-tembus-ritelmenko-darmin-pasar-modern-wajib-tampung [8 Jan. 2018].

15. R B, RS I. Wawancara. 2017.

16. Redaksi. 2.000 Pasar Tradisional Lenyap dari Peredaran | APPSI - Asosiasi Pedagang Pasar Seluruh Indonesia [Online]. [date unknown]. http://pedagangpasar.org/2015/12/2-000pasar-tradisional-lenyap-dari-peredaran/ [8 Jan. 2018].

17. TH. Wawancara. 2017.

18. Wahyuningtias D. Perencanaan Strategik Usaha Kecil Menengah Jenis Usaha Kue dan Roti. Binus Business Review 2: 564-570, 2011.

19. Presiden Jokowi Ingin Pasar Tradisional Tak Kalah dengan Mal - Berita - Kementerian Dalam Negeri - Republik Indonesia [Online]. [date unknown]. http://www.kemendagri.go.id/news/2017/01/3 0/presiden-jokowi-ingin-pasar-tradisional-takkalah-dengan-mal [8 Jan. 2018].

20. Minimarket Menjamur Dianggap Bukan Masalah [Online]. [date unknown]. https://www.borneonews.co.id/berita/28284minimarket-menjamur-dianggap-bukanmasalah [2 Jan. 2018]. 